\title{
Social work in the Quake zone: Supporting the sustainable development of Christchurch's eastern communities
}

\section{Raewyn Tudor}

Raewyn Tudor is a lecturer in the Human Services Department, Christchurch Polytechnic of Information and Technology. She has an interest in community-oriented social work particularly in school settings.

\begin{abstract}
This paper will focus on the role for social work intervention with people and communities affected by three major earthquakes in Christchurch, New Zealand. Since the first and subsequent earthquakes in September 2010 and February and June 2011, non-government agencies in Christchurch and the greater Canterbury region have been key providers of immediate crisis support. Whilst this type of service provision is not new territory for the social services, the impetus of the need and long-term nature of the earthquake recovery necessitates an expansive, responsive and empowering practice approach to facilitate ongoing sustainable development in the most affected communities. In consideration of the principles of sustainable development and Amartya Sen's Capabilities Approach (Seng, 1999), this article will examine ways of working with people beyond alleviating immediate problems towards restoring personal well-being, taking agency, exercising rights, connecting with others and becoming directly involved in the rebuild of Christchurch city and neighbourhood communities. These considerations provide an argument for expanding the scope of social work by reconceptualising its ecological framework and the work of individual and social change to respond to the needs of the affected people of Christchurch.
\end{abstract}

\section{Introduction}

On September 2010 and February and June 2011, the greater Christchurch area was struck by three significant earthquakes. The February earthquake resulted in 181 deaths and thousands of people's lives have been drastically changed. Whilst an earthquake makes no distinction between the areas it strikes or the lives it affects, certain characteristics of existing communities increase their vulnerability to the effects of natural disasters and present greater challenges for recovery. Communities with significant social and economic disparity tend to be more vulnerable to the effects of disasters; indeed, marginalised populations face greater challenges than their privileged counterparts in terms of disaster recovery (Pyles, 2009, p. 168). Social work's framework of social justice and its work predominantly with vulnerable groups means it has a crucial role to play in recognising and addressing the issues of structural inequality at hand. 
Before the earthquakes, like most cities, Christchurch was marked by lines of socio-economic difference (Howden-Chapman, et al., 2011). Whilst income, as a sole indicator, does not provide an accurate picture of health and well-being, it does reflect the ability of individuals to access goods and services such as food, accommodation expenses or other costs such as health care. According to Christchurch City Council data (Christchurch City Council, 2006), the eastern suburbs in the coastal areas of New Brighton and Rawhiti and further inland in Bexley and Aranui have the lowest median income levels in Christchurch. These areas were some of the worst hit by the earthquakes. A sustainability approach to Christchurch's recovery is advocated as a means to address the inequalities in the eastern communities, which have been adversely affected by the earthquakes.

\section{Sustainable development}

Sustainable development is defined as 'Development that meets the needs of the present without compromising the ability of future generations to meet their own needs' (The Brundtland Commission, 1987, p. 43). Balancing the social, economic and environmental objectives, a sustainable development approach response considers the short and long-term needs of communities. Sustainable development takes into account the issues and processes of improving the quality of life, the distribution and use of limited resources and the use of natural resources to sustain and create better lives (World Bank, n.d.). This approach, much like social work, highlights the value of human life and principles of fairness, equality and social justice as well as decision making that involves participation and partnership, and respect for the ecological constraints on the environment (Pyles, 2009, p. 169). However, the objectives of sustainable development challenge social work to adopt an ecological model which moves beyond the predominant focus on the relationships between a person and their social environment to an expansive understanding and recognition of the nonhuman world also (Jones, 2010, p. 69).

Sen's Capability Approach (Sen, 1999), which is grounded in the principles of self-determination, empowerment and collective responsibility, also offers direction for the role of social work in Christchurch's recovery.

\section{The Capability Approach}

Sen, an economist and philosopher, won a Nobel Peace Prize in 1998 for his contributions to welfare economics. The Capabilities Approach 'is based on the notion that human freedom and access to opportunities are central to social development' (Pyles, 2008, p. 27). Sen (1999) highlights three important characteristics of the approach, that of 'functionings', 'capabilities' and 'agency'.

Functionings are the various things a person may value doing or being; the 'beings and doings' of human life (Sen, 1999, p. 75). They can be basic things such as escaping or avoiding early death, nourishment and mobility, or more complex things such as respect, participation in community life and the ability to appear in public without shame. Capabilities are combinations of functionings that are feasible for a person to achieve (Sen, 1999, p.87). In Christchurch, freedom for individuals to rebuild their lives after the earthquakes is an important capability; functionings such as to be safe and calm, to renew friendships, to make decisions about one's living situation are invaluable. Capabilities reflect 'the per- 
son's freedom to lead one type of life or another ... to choose from possible livings' (Human Development and Capability Association (HDCA), n.d.). To attain their functionings people need the opportunity to achieve them, as well as the freedom to actively affect the processes influencing their own lives and the workings of society. They need to be able to take agency in pursuing and realising the goals that they value and have reason to value (HDCA, n.d.). According to Sen (1999, p. 19) an agent is 'someone who acts and brings about change'. 'The opposite of a person with agency is someone who is forced, oppressed or passive' (HDCA, n.d.).

Whilst individual responsibility is clearly emphasised in Sen's writing there is a strong connection with the notion of social responsibility within the framework. As people have greater freedom, then they are more able to influence the world. People are not seen as purely self-interested individuals only focused on their own life paths, but as sympathetic and committed to the freedoms of others. As social beings we care and are motivated not only about our own interests but also those of our family members, neighbours and fellow community members (Sen, 1999, p. 262); whether to end the suffering of an individual who is disadvantaged or to address structural inequalities which perpetuate the suffering of many. In Christchurch, after the initial aftermath of the earthquakes there were many examples of people helping each other, such activities ranging from people working together to shovel the silt off their streets, to checking in on each other and accessing water for each other.

The role of the Government and social institutions are central in ensuring people are able to enhance their own and other's wellbeing. The positive role of free and sustainable agency hinges on ideas that humans need to be able to be actively involved in enhancing their quality of life rather than passive recipients of the benefits of services and programmes (Sen, 1999, p.10). Adequate social opportunities for individuals to shape their own destinies play a pivotal role in determining the social values of people so that they are more inclined to consider the freedoms of others alongside their own. Engaging people into public discussions and social interactions are key processes in establishing these social norms and values and effectively making use of the concerns people do have (Drèze and Sen, 2002, p. 25). The Share an Idea forum held in Christchurch in April 2011 provided an opportunity for the public to tell the Council their ideas about how the city centre could be redeveloped over the next 10 to 20 years. Approximately 6,000 people participated in the month-long public consultation process which asked for feedback about the use of public spaces, the location of public facilities, how people and businesses could use the city and the types of buildings which could be rebuilt (Christchurch City Council (CCC), 2011). A significant role for social work is ensuring on-going opportunities for public discussions and collective action to provide people with basic capabilities associated with political and social participation, but also in playing a constructive role in the conceptualisation of needs and the formation of social policy (Sen, 1999, p.148).

\section{The Capabilities Approach and sustainable development for Christchurch}

In the initial aftermath of the earthquakes there can be no doubt that people's basic capabilities were infringed. The grief and loss for those who lost loved ones and for those who were displaced from their homes, their neighbours and friends, social and sporting clubs, schools and churches, has been enormous. Access to the necessities of 
modern life such as power, water and sewerage services was lost for the majority of the city for some time; whilst some have never fully regained these amenities. Figures show that 2,700 workers signed up for job loss cover because of the earthquake, with most having lost their jobs (New Zealand Press Association (NZPA), 2011a). There were large decreases in part-time, youth and female employment, and people employed in the retail trade and accommodation industry (Statistics New Zealand, 2011). The nature and make up of neighbourhoods and communities has changed significantly separating people from the networks and supports they have developed, those very aspects of their life which people need to draw on during the hard times (Canterbury Earthquake Recovery Authority (CERA), 2011b).

Social services were part of quick response teams which sought to provide immediate support and practical assistance to affected people. This service took many forms, such as 0800 phone lines offering advice and information, door knocking to check on people, accessible and free counselling and community welfare centres to provide food, temporary accommodation and support. Right Service Right Time, an integrated coordination service for access into community agencies, received 1,800 requests for help. After the February earthquake alone the call centre fielded 497 calls related to adult stress, 212 child stressrelated calls, 111 accommodation requests and 127 calls concerned with financial issues - all earthquake-related calls (Family and Community Services (FACS), n.d.).

Interestingly, despite an increase in the rates of depression and a growing demand for mental health services in the Canterbury region since September 2010, the figures show that there was a sharp decline in suicides after the February 22 earthquake (Johnston, 2011). This finding highlights the potential benefits when people are able to be active in supporting each other. According to David Fergusson, as reported by Johnston (2011) 'natural disasters earthquakes, hurricanes - often lead to declines in suicide rates due to increased community cohesion, friendliness and increased support.' Neighbours and communities were prompted to provide the most effective social support for each other.

Approximately 12,000 homes in the greater Christchurch area have been badly damaged (CERA, 2011a). CERA was set up by the Government to lead and coordinate the recovery work for the greater Christchurch area (CERA, 2011c). CERA has divided the Canterbury region into different land zones, of which there are currently three categories: red, green and white. Land in the red zones is deemed extensively damaged and too costly to repair ('Christchurch land rezoning', 2011). White zone land, which is predominantly located in the central city and hills, requires more assessment before its future viability can be decided ('Christchurch land rezoning', 2011). The green zone has been declared in areas where damage can be addressed on an individual basis as part of the normal insurance process (CERA, 2012). Delays in decisions about specific zones for the areas of Christchurch have kept large groups of homeowners in limbo as they await news on the future viability of their properties (NZPA, 2011b).

The Canterbury Earthquake Recovery Bill, passed in April 2011:

... sets out appropriate measures to enable the Minister for Canterbury Earthquake Recovery and / or the Canterbury Earthquake Recovery Authority (CERA) to facilitate and direct, if necessary, greater Christchurch and its communities to respond to, and recover from, the impacts of the Canterbury earthquakes (Parliament Today, 2011). 
CERA aims to work alongside the regional and local councils, the business sector and Ngai Tahu in the recovery effort (CERA, 2011b). A draft earthquake recovery strategy for greater Christchurch has been released and five key areas have been identified as priority considerations: (1) ensuring community wellbeing, (2) preserving culture and heritage, (3) rebuilding the environment, (4) sustaining the economy and (5) protecting the natural environment (CERA, 2011b). These are important considerations for the people of Christchurch and fit within a sustainable development framework. For social work as a profession to make a worthwhile contribution to the social, economic and political transformations required to make a sustainable future for Christchurch, a broader view of the ecological environment will need to be conceptualised (Jones, 2010, p. 68).

Enabling and empowering local communities to shape and lead the recovery in their neighbourhoods is cited as an important aim in the recovery strategy. Whilst this aim is a worthy focus, there is potential for unilateral decision making to undermine this in the name of economic necessity. The Canterbury Earthquake Recovery Bill allows the Minister for the Canterbury Earthquake Recovery and CERA the power to override legislation without the agreement of Parliament (Hopkins, 2011). Whilst this Bill will no doubt expedite some of the steps important for the rebuilding of communities, such as accessing land for development, the loss of emphasis on democratic decision making is a major concern.

The citizens of Christchurch cannot be assured that the Government will intervene on their behalf. Recently the Christchurch City Council expressed concern about a number of private insurance companies' policies and approaches to resolving earthquake damage claims to the extent that the Mayor of Christchurch identified that, 'Clearly there isn't an effective insurance market at the moment' (Cairns, 2012). Not having the mandate to make a complaint to the Insurance Ombudsmen, the Council has requested the Government intervene, given one of CERA's responsibilities is to ensure there is an effective insurance market (Migone, 2012). It's unclear at this point what the outcome will be, but given the response to a rental housing shortage in Christchurch, the likelihood of Government intervention may be low. Unaffordable housing, land supply restrictions and long-hauled consent processes are identified as underlying the housing crisis (Carville, 2012). However, the Canterbury Earthquake Response Minister has ruled out intervention, citing 'The solution is best left to the market' (Berry, 2012).

Accessing insurance cover for repairing and rebuilding homes is a growing issue, with many homeowners locked in disputes with their insurers (Cairns, 2012). In April 2012 homeowners in Brooklands, a red-zoned suburb on the northern outskirts of Christchurch, were told by their insurers that their homes, initially deemed 'rebuilds', are now repairable. Given the nature of the red zone land on which the houses are located the repairs are untenable, however, the insurers have cited changes in the Department of Building and Housing quake repair guidelines made in late 2011 as the basis for the re-assessments (Heather, 2012). According to Canterbury Community Earthquake Recovery Network (CanCERN) spokesperson Leanne Curtis, 'the rebuild-repair discrepancies would increase as more people were revisited under the new rules', and that these actions would be hard to fight legally given the re-assessments have occurred prior to settlement (Heather, 2012). Recently, IAG and Vero, the region's two biggest insurers, have issued statements outlining they will not pay to rebuild homes sold since the earthquakes as well as refusing to compensate for any accommodation costs for homeowners during repairs (McDonald, 2012). 
The uncertain and changing landscape of Government and private insurance policies are adversely impacting on people's ability to improve their life situation and stabilise their lives (Wright, 2012). As a result, burgeoning resident associations and emerging community groups such as CanCERN have become active as they work to rebuild their communities and unite to deal with concerns with the policies and actions of the Earthquake Commission (EQC) and insurance companies. CanCERN was set up to represent the interests of the earthquake-affected neighbourhoods in wider Christchurch, and its mandate is for full community engagement in recovery processes and to work in partnership with recovery agencies (CanCERN, n.d., para. 1). Collective action is vital in ensuring that people have the freedom to participate and influence local and national government policy and decision making which has a direct effect on them and their communities. Social work needs to align itself with such action in its commitment to challenging unjust social conditions and working with people, who are oppressed, to create social change.

For Christchurch, now more than ever, the preference needs to be for the generation of goals and processes of the recovery, based on informed and reflective public discussions. It is clear that the earthquakes have irrevocably changed the lives of Cantabrians and will continue to do so for some time before a full recovery can be made. The current vulnerability of the population will need to be taken into account during the recovery, alongside building locational and neighbourhood resilience (Howden-Chapman, et al., 2011, p. 20). Within this context social work practice will need to be informed by principles that resonate with sustainable development and Sen's Capability Approach.

\section{The earthquake recovery and implications for social work practice}

Like social work, the Capability Approach recognises that people's values and preferences are shaped by their social and economic lives. This approach connects well to the eco-systems perspective, which considers people within their environment. However, given the need in Christchurch to interface with the goals of sustainable development, social work needs to reconsider its limited conceptualisation of the environment, which too narrowly focuses on the social settings, such as a person's relationships with other individuals and groups, neglecting other aspects of the natural environment (Jones, 2010, p. 69). In Christchurch this focus is important, given the impetus of the need was created by changes to the natural environment with a resulting demonstration of the interdependent relationships for people with their homes, neighbourhoods, work places, schools, neighbourhoods and communities.

Te Whare Roimata, a community development organisation based in the east of inner city Christchurch, recognised the need to focus on the environment in which their community members live. For these residents, many of whom live in bedsits and rental housing in the area, there is a risk that their interests will be overlooked in favour of those of business investment and in an effort to draw professionals and their families into the central city. Recognition and protection at national and local government levels of the interests and the natural environment of those who currently call the eastern inner city home is of the upmost importance. By raising consciousness and through mobilisation, Te Whare Roimata was able to ensure that community members participated in the both written and verbal submissions for the Christchurch City Council's long-term plan for the redevelopment of Christchurch central business district, as well as to CERA on the Wider Christchurch Recovery draft plan. 
Additionally Te Whare Roimata has undertaken research on ways government can respond to preserve and protect affordable low-cost housing in the neighbourhood.

An adjunct to Te Whare Roimata is the Latimer Community Housing Trust, which was set up some years ago with the view to purchase affordable, quality low-cost housing in the area. The Trust has begun to explore possible partnerships with the view to making an initial purchase of land. Additionally steps are underway to bring key stakeholders together from the Inner City East to look at a collective response to housing the people who have been displaced by the earthquakes.

Since the aftermath of the earthquakes there has been a move to focus support services on recovery rather than relief. This is an important transition; the people of Christchurch need to be active in moving forward and shaping their future directions. However, small-scale interventions on their own can do little to provide capabilities. People need adequate social opportunities to shape their own destinies, necessitating greater emphasis on increasing the opportunities that people have to connect with one another. Social workers need to be based in the communities in which the affected people live and interact. Connecting people with existing community groups such as resident associations, schools, church groups and community networks in democratic activities will serve to enhance political freedoms and increase social opportunities. Traditional social work skills must be supplemented by the skills of community development such as organising and community mobilisation (Pyles, 2008, p. 33).

Alongside the work of Te Whare Roimata, there are other grassroots organisations which having long-established relationships with community members and neighbourhoods in the eastern suburbs. One such agency, the Aranui Community Trust (ACTIS) has partnered with Presbyterian Support (Upper South Island) by allocating a social worker to provide direct support to families in need and participate in creating initiatives which support the social development of the Aranui community. This relationship was established following the September 2010 earthquake through the use of Ministry of Social Development (MSD) Earthquake Recovery Funding and initially the worker, alongside ACTIS staff, was involved in visiting all the residents in the community to check on their emotional and social status and offer support. This work has evolved from being crisis driven to the development of a number of initiatives with a key focus on reducing isolation and supporting the inclusion of older people in their their community. This includes, for example, a housie group run in partnership with St Ambrose Church, which also hosts a 'drop-in' at which the social worker is present.

A key priority for social services and social workers working within the Eastern suburbs is that of partnership with existing community groups. Without such a commitment true community engagement cannot occur. Both ACTIS and Te Whare Roimata are members of CanCERN alongside 33 other representatives from established residents' associations and community groups in Canterbury. Integrating social work and community development approaches fits well with social work's commitment to social justice; in that personal troubles are connected with broader social and political structures and interventions (Mendes, 2008, p. 249). The people of Christchurch have shown themselves to be supportive of and helpful to each other in times of need, and protecting this emergent social capital will ensure the creation of places of belonging for years to come. 


\section{Conclusion}

It should be clear from the above discussion that social workers need to purposeful in their important work in the long-term sustainable recovery of Christchurch. Of the upmost importance is practice which prioritises the rights of each person to decide what is in their best interests in cooperation and reciprocity with others (Morris, 2002, p. 368). The principles of sustainable development, as related to the Christchurch context, provide the impetus for social work to adopt a broadened ecological model of practice. The Capabilities Approach offers a social justice framework challenging the binary approach to social work and identifying ways to integrate the practices of both individual and social change. By engaging with existing community groups, schools and networks, social opportunities and political freedoms can be achieved. Social work can play an important role in the recognition of the vulnerabilities and challenges facing Eastern Christchurch and facilitating people to be able to exercise their rights and work together to rebuild their communities.

\section{References}

Berry, M. (2012, 20 March). Rebuild firms 'should house staff'. The Press. Retrieved from http:/ / www.stuff.co.nz / the-press / business / your-property / 6601543 / Rebuild-firms-should-house-staff.

Cairns, L. (2012, 12 July). Council asks for urgent insurance help. The Press. Retrieved from http: / / www.stuff.co.nz / the-press / news / christchurch-earthquake-2011/7267022/Council-asks-for-urgent-insurance-help.

Carville, O. (2012, 13 April). Housing crisis: State must step in, says economist. The Press. Retrieved from http:/ / www.stuff.co.nz/business / rebuilding-christchurch/6734665/Housing-crisis-State-must-step-in-says-economist.

Christchurch City Council (CCC). (2006). Median annual family income. Retrieved from http://www.ccc.govt.nz/ cityleisure/statsfacts / census / income.aspx\#jumplink7.

Christchurch City Council (CCC). (2011, May 6). Share an idea for the redevelopment of our Central City. Retrieved from http: / / www.ccc.govt.nz/ thecouncil/newsmedia/mediareleases/2011 / 201105061.aspx.

Canterbury Earthquake Recovery Authority (CERA). (2011a). CERA calls for information on planned housing developments. Retrieved from http: / / cera.govt.nz/news/cera-calls-for-information-on-planned-housing-developments-31-may-2011.

Canterbury Earthquake Recovery Authority (CERA). (2011b). Recovery strategy. Retrieved from http:/ / cera.govt. $\mathrm{nz} /$ recovery-strategy.

Canterbury Earthquake Recovery Authority (CERA). (2011c). About CERA. Retrieved from http: / cera.govt.nz/ about-cera.

Canterbury Earthquake Recovery Authority (CERA). (2012). Zoning review. Retreived from http:/ / cera.govt.nz/ zoning-review.

Christchurch land zoning explained. (2011, June 23). TVNZ. Retrieved from http:/ / tvnz.co.nz/national -news/ christchurch-land-zoning-explained-4260110.

Dalrymple, J., \& Burke, B. (2006) Anti-oppressive practice: Social care and the law, (2nd Ed.). New York, NY: Open University Press.

Drèze, J., \& Sen, A. (2002). India: Development and participation, (2nd Ed.). Oxford: Oxford University Press.

Family and Community Services (FACS). (n.d.). Right Service Right Time shaken out by quake. Retrieved on 23 August, 2011, from http: / / www.familyservices.govt.nz/working-with-us / news-room/newsletters / community-connect/issue-12/right-service-right-time.html.

Heather, B. (2012, 12 April). Homes assessed as writeoffs become repairs. The Press. Retrieved from http: / / www.stuff. co.nz/the-press / news / christchurch-earthquake-2011/6727056/Homes-assessed-as-writeoffs-become-repairs.

Hopkins, J. (2011, April 14). CERA bill threatens democracy. The Press. Retrieved from http:/ / www.stuff.co.nz/ the-press / opinion / 4885510/Cera-bill-threatens-democracy.

Howden-Chapman, P., Chapman, R., Abrahamse, W., Awatere, S., Fougere, G., Frame, B., Krausse, M., Hayward, B., Mortimer, C., Stevenson, A., \& Logie, J. (2011). Christchurch's regeneration: Research and science-based insights. New Zealand Centre for Sustainable Cities. Retrieved from www.sustainablecities.org.nz.

Human Development and Capability Association (HDCA). (n.d.). Capability and functionings: Definition E justification. Retrieved from http:/ / www.capabilityapproach. com/ pubs/HDCA_Briefing_Concepts.pdf.

Johnston, M. (2011, August 27). Quake zone 'cohesion' cuts suicide rate. The NZ Herald. Accessed from http:/ / www.nzherald.co.nz/ christchurch-earthquake/news/article. cfm?c_id=1502981 \&objectid=10747697.

Jones, P. (2010). Responding to the ecological crisis: Transformative pathways for social work education. Journal of Social Work Education, 46(1), 67-83. DOI: 10.5175/JSWE.2010.200800073.

McDonald, L. (2012, 16 July). Homeowners lose as insurers get tough. The Press. Retrieved from http:/ / www. stuff.co.nz/the-press / news / christchurch-earthquake-2011/7282867/Homeowners-lose-as-insurers-get-tough. 
Mendes, P. (2008). Teaching community development to social work students: A critical reflection. Community Development Journal, 44(2), 248-262. doi: 10.1093/cdj/bsn001.

Migone, P. (2012, 18 July). Government considers insurance help for Christchurch residents. The Press. Retrieved from http: / / www.stuff.co.nz / national/ 7300743 / Government-considers-insurance-help-for-Christchurch-residents.

Morris, P.M. (2002). The capabilities perspective: A framework for social justice. Families in Society, 83(4), $365-373$. doi: 10.1606/1044-3894.16.

New Zealand Press Association (NZPA). (2011a, March 4). Christchurch workers sign up for job loss cover. The New Zealand Herald. Retrieved from http:// www. nzherald.co.nz/ business/news/article.cfm?c_id=3\&objectid=10710102.

New Zealand Press Association (NZPA). (2011b, April 14). CERA bill threatens democracy. The Press. Retrieved from http: / / www.stuff.co.nz/ the-press / opinion/4885510/Cera-bill-threatens-democracy.

Parliament Today. (2011, April 12). Canterbury earthquake bill now on-line. Retrieved on from http:/ / parliamenttoday. co.nz/2011/04/ canterbury-earthquake-recovery-bill-now-on-line/.

Pyles, L. (2008). The capabilities approach and violence against women: Implications for social development. International Social Work, 51(1), 25-36. doi: 10.1177/0020872807083912.

Pyles, L. (2009). Neoliberalism, INGO practices and sustainable disaster recovery: A post-Katrina case study. Community Development Journal, 46(2), 168 - 180. doi: 10.1093 / cdj/bsp058.

Sachdeva, S. \& Levy, D. (2011, August 3). 26,000 hit the road after quake. The Press. Accessed from http:/ / www. stuff.co.nz/the-press / news / christchurch-earthquake-2011/5379410/26-000-hit-the-road-after-quake.

Sen, A. K. (1999). Development as freedom. New York, NY: Anchor Books.

Sheafor, B. W., \& Horejsi, C.R. (2008). Techniques and guidelines for social work practice. (8th Ed). Boston, MA: Allyn \& Bacon.

Statistics New Zealand. (2011). Canterbury labour market: A snapshot after the 22 February 2011 earthquake. Accessed from http: / / www.stats.govt.nz/browse_for_stats / income-and-work/employment_and_unemployment / Canterbury-suffers-after-quake.aspx.

Stewart, T., \& Steeman, M. (2011, March 9). Insurers halt new policies after Christchurch earthquake. The NZ Herald. Accessed on from http: / / www. stuff.co.nz/business / money / 4745841/Insurers-halt-new-policies-after-Christchurch-earthquake.

The Brundtland Commission. (1987). Our common future. The World Commission on Environment and Development. Oxford: Oxford University Press.

The World Bank. (n.d.). What is sustainable development? Retrieved from http:/ / www.worldbank.org/depweb/ english/sd.html.

Wright, M. (2012, April 18). Insurance firm stands by claim downgrades. The Press. Retrieved from http:/ / www. stuff.co.nz/ the-press / business / your-property / 6760725/Insurance-firm-stands-by-claim-downgrades. 